\title{
Planning island sustainable development policy based on the theory of ecosystem services: A case study of Zhoushan Archipelago, East China
}

\author{
Huan Zhang \\ College of Civil Engineer and Architecture, Zhejiang University, China \\ 0014979@zju.edu.cn
}

\section{Yang Xiao}

College of Biology and Environmental Sciences, Jishou University, China yangxiao84@hotmail.com (corresponding author)

\begin{abstract}
Island ecosystems and living conditions are undergoing rapid change as human populations are increasingly concentrated in coastal regions. Many island economies have transitioned from an emphasis on primary sector production to reliance on tourism, port, and shipping industries. This has driven processes of large-scale construction and urbanization, occasioning drastic changes in island ecosystems and enhancing the importance of understanding ecosystem service mechanisms on islands. This paper explores the spatial distribution and interactions of ecosystem services in East China's Zhoushan Archipelago and how these should affect the island's sustainable development policy. The results show that the archipelago's total ecosystem services hold great potential but that there are significant trade-offs and synergy relations, which vary on different islands in the archipelago. Cultural services are mainly distributed across the northeastern and southeastern regions, with plentiful natural scenery and Buddhist cultural heritage, which are attractive to tourists. Provisioning services show a negative correlation between cultural services and regulating services, indicating strong trade-offs between them. However, the synergy areas between cultural and regulating services might become priorities for future policies. These are mostly situated in the rural eastern part of the archipelago. The island planning policy proposed in this paper, based on the ecosystem services theory and sensitive to intra-archipelagic differences, contributes to efforts at island sustainable development by seeking to resolve tensions between economic development and environmental protection.
\end{abstract}

Keywords: China, ecosystem services, islands, sustainable development, trade-offs, Zhoushan Archipelago

https://doi.org/10.24043/isj.105 • Received November 2018, accepted September 2019

(C) 2020-Institute of Island Studies, University of Prince Edward Island, Canada. 


\section{Introduction}

This paper examines the spatial distribution and interaction between ecosystem services in China's Zhoushan archipelago. In so doing, it sheds light on the importance of locally contextualized understandings of ecosystem service mechanisms of change, with the aim of helping to resolve the frequent tension between economic development and environmental protection.

Ecosystems and human systems are intrinsically linked, and their interactions are critical to human welfare. Ecosystems support the development of human systems through the supply of ecosystem services (Daily et al, 2000; Costanza et al, 2014), and human activities have the potential to influence ecosystem functions. Studies indicate that the tendency for human populations and settlements to move toward coastal areas will continue to accelerate in the future (Bertolo et al, 2012; Bateman et al, 2013). Many islands are undergoing rapid urban expansion, with increasing coastal developments such as island tourism, island special economic zones, coastal city agglomeration, and ports and marinas (Bertolo et al, 2012; Qiu et al, 2017; Grydehøj, 2019). Scientific technology and the marine economy will likewise continue to advance as drivers of global development, and coasts and islands will increasingly become an area of international competition (Chen et al, 2013).

China's continental coastline is densely populated with near-shore islands, which form a boundary and transition zone between the ocean and the mainland. Islands are thus not only important for the marine economy but can also function as a vital fulcrum for a country's interaction with the sea (Lin et al, 2013). The East China Sea Region, in which Zhoushan Archipelago is located, includes $60 \%$ of China's islands and is also the frontier for China's opening up and engagement with the global economy.

In recent years, China has successively set forth a number of localized island-oriented development strategies, including the Zhoushan Archipelago New Area, in order to anchor the 'River-Sea Intermodal Transport' 江海联运 strategy, which refers to goods being transported by the same ship without transshipment. In China, this kind of transport is primarily used in the Yangtze River Delta and is the main mode of transportation for foreign trade. The implementation of such strategies can help island industries prosper and island populations grow. However, in the case of Zhoushan Archipelago, rapid economic development has revealed tensions between pursuing economic growth and valuing islands' ecological resources. Most of the islands in Zhoushan Archipelago represent a convergence of fragile terrestrial and marine ecosystems, and their environments are vulnerable to natural disasters and human-induced environmental degradation, contributing to risks from storms, erosion, and coastal industrial pollution. Many islands have steep slopes, weak environmental human carrying capacities, and uneven spatial and temporal distribution of water resources. As a result, the rapid development of islands may raise particular kinds of problems. Much attention has been paid to traffic logistics, land use planning, and economic development planning, while too little consideration has been given to islands' ecological patterns, ecosystem services, and other environmental factors (Wang et al, 2010; Lin et al, 2013).

The development goals for different types of islands in Zhoushan Archipelago are unclear and often inappropriate. The rapid urbanization of some islands and the tendency for undifferentiated planning and construction are linked to the city government's 'One Appearance of a Thousand Islands' 千岛一面 development plan, which seeks to manage Zhoushan 
Archipelago's numerous islands as a single unit. Although it is positive that this development plan attempts to undertake integrated planning within the archipelago, it may-as we argue below-be problematic for the strategy to treat the various islands as a homogenous group. In Zhoushan Archipelago, dominant archipelagic development strategies fail to consider cultural and environmental conditions on individual islands, resulting in overload, homogenization, and loss of natural resources. This risks having a strongly negative impact on island ecology and human environments (Qiu et al, 2017).

Unless efforts are made to understand the mechanisms of change within internally varied archipelagos, it will prove difficult to guide island development in a positive direction. There is thus an urgent need to use an integrated research method to adjust planning policies and manage future risks, so as to achieve the goal of regional sustainable development.

This paper seeks to address the balance between development and conservation in Zhoushan Archipelago. We first analyze selected indicators for various types of ecosystem services in Zhoushan Archipelago: food supply, tourism recreation, water storage, carbon sequestration, soil retention, and flood mitigation. Next, we analyze changes in ecosystem services supply in each county in the archipelago as well as the spatial distribution of ecosystem services. We discuss means of establishing ecological management of Zhoushan's ecosystem resources and tourism resources. Through our analysis of the balance and coordination of ecosystem services and sustainable development in a key region, we argue that planning for sustainable island resource use is an important scientific issue in need of urgent study.

\section{Materials and methods}

Study area

Zhoushan Archipelago is located in northeastern Zhejiang Province, between $121^{\circ} 30^{\prime}-123^{\circ} 20^{\prime} \mathrm{E}$ and $29^{\circ} 45^{\prime}-31^{\circ} 08^{\prime} \mathrm{N}$ (Figure 1). It is at the intersection of East China's coastline and the estuary of the Yangtze River. Zhoushan Archipelago is China's largest archipelago and its first prefecturelevel administrative region with islands (including Dinghai District, Putuo District, Daishan County, and Shengsi County). It covers a total area of 22,200 $\mathrm{km}^{2}$, with a land area of $1,400 \mathrm{~km}^{2}$ and a sea area of $20,800 \mathrm{~km}^{2}$. Zhoushan Archipelago supports a permanent population of 1.14 million (Bureau of Zhoushan Statistics, 2016), though its total population is considerably higher.

The islands in the archipelago have a generally hillier and more mountainous terrain to the southwest and are lower to the northeast. Most of the large islands are in the south, with relatively high mountains and tighter clustering, while the smaller islands in the north tend to be separated by wider expanses of sea. The maximum altitudes of most hills are lower than 250 $\mathrm{m}$, though the highest peak reaches $500 \mathrm{~m}$. Most of the plains are under $3 \mathrm{~m}$. Zhoushan Archipelago belongs to the marine monsoon climate zone at the southern margin of the northern subtropical zone. The islands are mild and humid, with four distinct seasons. The average annual temperature is $15.8-16.7^{\circ} \mathrm{C}$, and the archipelago averages $2025-2262$ hours of sunshine annually. The annual average precipitation level is $1356.3 \mathrm{~mm}$, and the islands possess an annual frost-free period of 254-293 days, making the area suitable for the multiplication and growth of various biological communities. The main forest types are coniferous forests, evergreen broadleaf forests, and deciduous broad-leaf forests. The dominant soil types are red soil, yellow soil, coastal saline soil, paddy soil, and coarse bone soil. 
As an emerging political economic and cultural center, Zhoushan Archipelago has undergone unprecedented urbanization in recent decades, with a growing population and economy, dominated by port services, island tourism development, and marine products. This development has been accompanied by significant changes in land use and land cover, which have exerted great pressure on the islands' limited land resources and ecosystems.

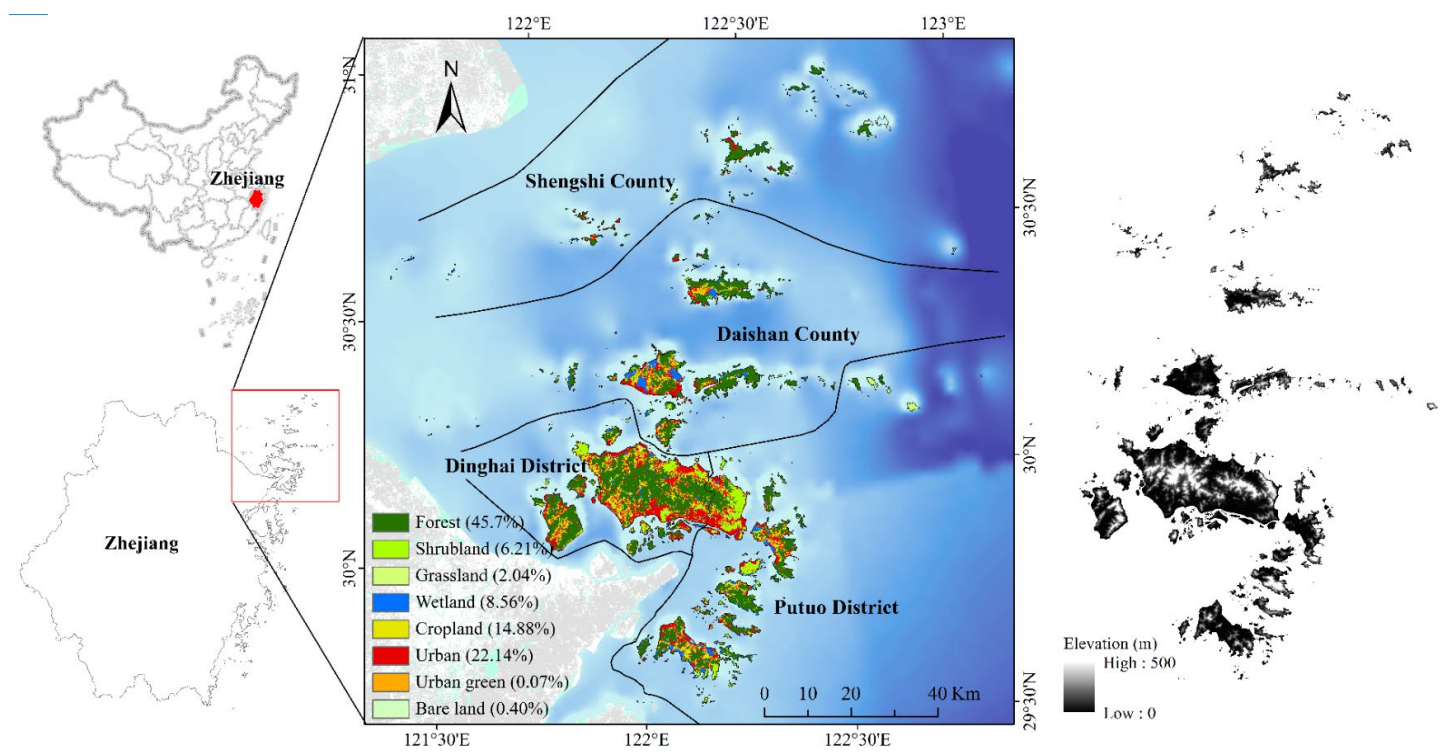

Figure 1: Map of the Zhoushan Archipelago and its land use cover pattern in 2015.

Data sources

Information related to the distribution of land use and land cover (LULC, 2015) was generated with object-oriented image classifications using Landsat OLI satellite image data, with a classification accuracy of $86.52 \%$ (http://www.irsa.ac.cn). Digital elevation model (DEM) data originated from the Shuttle Radar Topography Mission (SRTM), with a resolution of $30 \mathrm{~m}$ (http://dwtkns.com/srtm30m/). The meteorological data, including precipitation and temperature, was obtained from the Chinese National Meteorological Information Center. The meteorological data from the station-based information was interpolated to the whole research area with a spatial resolution of $1 \mathrm{~km}$ using the Kriging interpolation method. Evapotranspiration and Net Primary Production (NPP) at $250 \mathrm{~m}$ spatial resolution were obtained from the Land Processes Distributed Active Archive Center. The vegetation cover, as a key indicator of the condition of vegetation, was generated with NDVI (calculated from Landsat image) and LULC using dimidiate pixel model. We collected soil data from the second national soil survey. This data included soil type, soil particle composition, soil organic matter content, and soil depth at a scale of 1:1,000,000. The other data (such as that related to boundaries, roads, etc.) was collected from the local government. The sources of principal data are shown in Table 1. All the cartographic raster data was converted into the same Universal Transverse Mercator (UTM) with a spatial resolution of $30 \mathrm{~m}$. 
Table 1: Sources of principal data.

\begin{tabular}{|c|c|c|}
\hline Data name & $\begin{array}{l}\text { Data } \\
\text { resolution }\end{array}$ & Data source \\
\hline LULC maps & $30 \mathrm{~m}$ & $\begin{array}{l}\text { The Institute of Remote Sensing Applications, Chinese } \\
\text { Academy of Sciences (http://www.irsa.ac.cn) }\end{array}$ \\
\hline DEM & $30 \mathrm{~m}$ & $\begin{array}{l}\text { The NASA Shuttle Radar Topographic Mission (SRTM) } \\
\text { (http://dwtkns.com/srtm } 30 \mathrm{~m} / \text { ) }\end{array}$ \\
\hline $\begin{array}{l}\text { Precipitation and } \\
\text { temperature }\end{array}$ & Points & $\begin{array}{l}\text { Chinese National Metrological Information Center/ China } \\
\text { Meteorological Administration } \\
\text { (http://data.cma.cn) }\end{array}$ \\
\hline Evapotranspiration & $250 \mathrm{~m}$ & $\begin{array}{l}\text { Land Processes Distributed Active Archive Center } \\
\text { (https://lpdaac.usgs.gov/) }\end{array}$ \\
\hline NPP & $250 \mathrm{~m}$ & $\begin{array}{l}\text { Land Processes Distributed Active Archive Center } \\
\text { (https://lpdaac.usgs.gov/) }\end{array}$ \\
\hline MODIS-NDVI & $250 \mathrm{~m}$ & $\begin{array}{l}\text { Land Processes Distributed Active Archive Center (LP } \\
\text { DAAC) ( } \underline{\text { https://lpdaac.usgs.gov } /)}\end{array}$ \\
\hline Soil map & $1: 1,000,000$ & $\begin{array}{l}\text { Institute of Soil Science, Chinese Academy of Sciences } \\
(\text { www.issas.cas.cn/) }\end{array}$ \\
\hline
\end{tabular}

\section{Ecosystem services}

In order to explore the characteristics of major ecosystem services in Zhoushan Archipelago, we selected a number of key ecosystem services, including crop production, tourism, water storage, carbon sequestration, soil conservation, and flood regulation (Table 2) due to significance, relevance for land use planning, and data availability. These likewise account for a high proportion of GDP (crop production, tourism), are key survival resources (water storage, carbon sequestration), and are related to important natural hazards (soil conservation, flood regulation).

Table 2: Main indicators and data for quantifying ecosystem services in Zhoushan Archipelago.

\begin{tabular}{|c|c|c|c|}
\hline \multicolumn{2}{|l|}{$\begin{array}{l}\text { Ecosystem } \\
\text { services }\end{array}$} & \multirow{2}{*}{$\begin{array}{l}\text { Indicators } \\
\text { Annual crop yield }\end{array}$} & \multirow{2}{*}{$\begin{array}{l}\text { Main data } \\
\text { LULC, field measurements, statistical } \\
\text { data, net primary production }\end{array}$} \\
\hline $\begin{array}{l}\text { Provisioning } \\
\text { services }\end{array}$ & Crop production & & \\
\hline $\begin{array}{l}\text { Cultural } \\
\text { services }\end{array}$ & Tourism & $\begin{array}{l}\text { Scenery score } \\
\text { Culture score }\end{array}$ & LULC, DEM, scenic survey data, road \\
\hline \multirow[t]{4}{*}{$\begin{array}{l}\text { Regulating } \\
\text { services }\end{array}$} & Water storage & $\begin{array}{l}\text { Water retention } \\
\text { capacity }\end{array}$ & $\begin{array}{l}\text { LULC, rainfall, evapotranspiration, and } \\
\text { runoff }\end{array}$ \\
\hline & $\begin{array}{l}\text { Carbon } \\
\text { sequestration }\end{array}$ & $\begin{array}{l}\text { Net ecosystem } \\
\text { productivity }\end{array}$ & $\begin{array}{l}\text { LULC, heterotrophic respiration, net } \\
\text { primary production, soil map }\end{array}$ \\
\hline & Soil conservation & $\begin{array}{l}\text { Soil retention } \\
\text { capacity }\end{array}$ & $\begin{array}{l}\text { LULC, rainfall, DEM, soil map, } \\
\text { vegetation cover }\end{array}$ \\
\hline & Flood regulation & $\begin{array}{l}\text { Flood regulation } \\
\text { capacity }\end{array}$ & LULC, heavy rainfall, storm runoff \\
\hline
\end{tabular}

(1) Crop production: The amount of agricultural production can be calculated on the basis of survey data, net primary production, LULC, and statistical data (Bureau of Zhoushan Statistics, 2016). We interpolated the sample data (30 $\mathrm{m}$ spatial resolution), collected from field measurements, to the entire study area, using a thin plate smoothing spline method with net primary production as a covariate in the ANUSPLIN software package (Xiao et al, 2018). This has been widely used for regionalizing variables at different scales (Johnson et al, 2016). The main 
agricultural crops include barley in its early and late stages of production, rice, corn, sweet potato, rapeseed, cotton, fruits, and vegetables (Bureau of Zhoushan Statistics, 2016). Accuracy was assessed by comparing our estimates with statistical data and field measurements for this region.

(2) Tourism: The score for tourism was primarily influenced by the accessibility (distance to the traffic road), visibility (from), and tourists' evaluation of scenic spots (Chen et al, 2009). The evaluation score of raster's tourism decreases with distance from scenic spots and increases with visibility from scenic spots.

The spatial analysis for tourism involved three formulas, as shown below:

$$
\begin{gathered}
T R_{s} s=L_{a} * L_{v} \\
T R_{c}\left(s_{0}\right)=\sum_{i=1}^{n} \lambda_{i} \times Z\left(s_{i}\right)
\end{gathered}
$$

where $T R_{s}$ is the score of tourism scenery and $L_{a}$ and $L_{v}$ are the score layer in reference to the accessibility and visibility from the scenic spots respectively. $\mathrm{L}_{\mathrm{a}}$ was calculated via distance analysis method, which was carried out based on road map in GIS layer. We assume that maximum distance of human activity is $5000 \mathrm{~m}$, with intervals of $500 \mathrm{~m}$ and corresponding degrading intervals of $5 \%$. The $\mathrm{L}_{\mathrm{v}}$ was calculated via viewshed (or visibility) analysis method, which determines the raster surface locations visible to a set of observer features (scenic spots). The viewshed tool of ArcGIS with DEM was used to determine this value (Chen et al, 2009). This analysis did not account for height of vegetation. $\mathrm{TR}_{\mathrm{c}}$ is the score of tourism culture derived from the evaluation of tourists, which is interpolated by applying kriging (Piao et al 2001) with a spatial resolution of $30 \mathrm{~m}$, based on the field survey data (Buddhist culture) and online scoring data drawn from Baidu (https://map.baidu.com/). Buddhist culture is relevant here because Zhoushan Archipelago is a major site for religious and cultural heritage tourism related to significant Buddhist sites. The field survey mainly includes the GPS location of major scenic spots, tourists' willingness to pay, and visitors' subjective ratings, while the online scoring was calculated through an online rating system based on tourists who had been to the scenic area (five stars represents the highest rating and one star the lowest). $\mathrm{Z}\left(\mathrm{s}_{\mathrm{i}}\right)$ is the observed data at location $i ; \lambda$ is the unknown weight of the observed value at the ith position; $n$ is the total number of observed data; and $\mathrm{s}_{\mathrm{o}}$ is the predicted location.

(3) Water storage: The revised Integrated Valuation of Ecosystem Services and Tradeoffs (InVEST) model is used to quantify water storage based on the water balance principle, shown as follows:

$$
\begin{gathered}
W R=\left(P-E T-R_{a}\right) \times \mathrm{A}_{\mathrm{i}} \times 10^{-3} \\
R_{a}=P_{h} \times \alpha
\end{gathered}
$$

where $W R$ denotes the water storage for each pixel $\left(\mathrm{m}^{3} \mathrm{yr}^{-1}\right) ; P$ is the rainfall for each pixel $(\mathrm{mm}$ $\left.\mathrm{yr}^{-1}\right)$; ET is the actual evapotranspiration for each pixel $\left(\mathrm{mm} \mathrm{yr}^{-1}\right)$; and $R_{\mathrm{a}}$ is the surface runoff for each pixel $\left(\mathrm{mm} \mathrm{yr}^{-1}\right)$, whereas $A \mathrm{i}$ is the area of the ecosystem $\left(\mathrm{m}^{2}\right) . R_{\mathrm{a}}$ can be described as the product of rainfall that produces runoff $\left(\mathrm{P}_{\mathrm{h}}\right)$ times runoff coefficient $(\alpha)$ (Xiao et al, 2019). The $\mathrm{P}_{\mathrm{h}}$ can be calculated from daily heavy precipitation (rainfall $>25 \mathrm{~mm}$ per day) that would generate surface runoff times the number of days per year (Xiao et al, 2019).

(4) Carbon sequestration: Carbon sequestration is the process of long-term capture and storage of atmospheric $\mathrm{CO}_{2}$, and is proposed as a mitigation of global warming (Xiao et al, 2016). The annual amount of $\mathrm{CO}_{2}$ sequestrated by the ecosystem can be estimated based on net ecosystem productivity (NEP) (Christie et al 2012), defined as follows: 


$$
\begin{gathered}
N E P=N P P-0.592 \times R s^{0.714} \\
R_{S}=1.55 e^{0.031 T} \times \frac{P}{P+0.68} \times \frac{S O C}{S O C+2.23} \times 0.001
\end{gathered}
$$

where NEP denotes the value of carbon sequestration over time $\left(\mathrm{g} \mathrm{C} \mathrm{m}^{-2} \mathrm{yr}^{-1}\right)$; NPP is the net fixation of $\mathrm{CO}_{2}$ by the ecosystem $\left(\mathrm{g} \mathrm{C} \mathrm{m}^{-2} \mathrm{yr}^{-1}\right)$ and can be calculated using the Carnegie Ames Stanford Approach (CASA) based on light use efficiency (LUE) (Potter et al 1993); and Rs, as soil respiration $\left(\mathrm{g} \mathrm{C} \mathrm{m}^{-2} \mathrm{yr}^{-1}\right)$, can be calculated with reference to Chen's methods (Chen et al 2009). T is average annual air temperature $\left({ }^{\circ} \mathrm{C}\right)$; $\mathrm{P}$ is annual precipitation $(\mathrm{mm})$; SOC $(\mathrm{kg} \mathrm{C} \mathrm{m-}$ 2 ) is the topsoil organic carbon storage and can be calculated with reference to Chen's methods (Chen et al 2012).

(5) Soil conservation: Soil conservation can be expressed as the difference between potential and actual soil erosion (Fu et al, 2011). According to the universal soil loss equation (USLE), soil erosion is closely related to rainfall erosivity, soil erodibility, topography, vegetation, and conservation practice (Wischmeier \& Smith, 1978). The amount of soil conservation can thus be defined as:

$$
S C=R \times K \times L S \times(1-C \times P)
$$

where $S C$ denotes the soil conservation capacity $\left(\mathrm{t} \mathrm{ha}^{-1} \mathrm{yr}^{-1}\right) ; R$ is the annual rainfall erosivity (MJ mm ha ${ }^{-1} \mathrm{~h}^{-1} \mathrm{yr}^{-1}$ ) calculated with an empirical equation (Fu et al 2011), $K$ is the soil erodibility ( $\mathrm{t}$ ha h ha-1 $\mathrm{MJ}^{-1} \mathrm{~mm}^{-1}$ ) quantified by the Erosion/Productivity Impact Calculator (EPIC) model (Zhang et al, 2008), and $L S$ the topographic factor, reflecting the impact of slope length and steepness on soil erosion. The latter is calculated with the help of an Arc Macro Language (AML) script in ArcGIS (Hickey, 2000). As far as the last two values are concerned, $C$ is the dimensionless vegetation cover factor estimated by the method using the form of NDVI (Fu et al 2011), and $P$ is the dimensionless conservation practice estimated by the Wener method (Lufafa et al, 2003).

(6) Flood mitigation: Natural vegetation and lakes/reservoirs can regulate stream flows and mitigate flooding by storing water temporarily. The formula is as follows:

$$
\mathrm{C}_{\mathrm{fm}}=\mathrm{C}_{\mathrm{fc}}+\mathrm{C}_{\mathrm{lc}}+\mathrm{C}_{\mathrm{rc}}
$$

$\mathrm{C}_{\mathrm{fm}}$ is the total mitigated flood water $\left(\mathrm{m}^{3}\right), \mathrm{C}_{\mathrm{fc}}$ is the mitigated water of natural vegetation $\left(\mathrm{m}^{3}\right)$, while $\mathrm{C}_{\mathrm{lc}}$ and $\mathrm{C}_{\mathrm{rc}}$ are the mitigated water of lakes and reservoirs $\left(\mathrm{m}^{3}\right)$ respectively. For natural vegetation (forest, shrub, and grassland), the mitigated flood was calculated based on the relationship between heavy precipitation and surface runoff of storm:

$$
\mathrm{C}_{\mathrm{fc}}=\sum_{\mathrm{i}=1}^{\mathrm{j}}\left(\mathrm{P}_{\mathrm{hi}}-\mathrm{R}_{\mathrm{fi}}\right) \times \mathrm{A}_{\mathrm{i}} \times 10^{-3}
$$

$\mathrm{C}_{\mathrm{fc}}$ is the mitigating capacity of natural vegetation, while $\mathrm{P}_{\mathrm{hi}}$ is the heavy storm rainfall (rainfall $>50 \mathrm{~mm}$ per day), $R_{\mathrm{fi}}$ is the storm surface runoff $(\mathrm{mm})$ which was identified using runoff coefficients (Ouyang, et al, 2016), and Ai is the area of the ecosystem $\left(\mathrm{m}^{2}\right)$. The mitigated flood for lake and reservoir was calculated according to the methods of Ouyang's research (2016).

Trade-offs and synergies analysis

To explore the trade-offs and synergies relationship between provisioning services, cultural services, and regulating services, a Pearson correlation was performed. In this study, we used a GIS tool (https://www.arcgis.com/) to create hexagon polygon with a resolution of $1 \mathrm{~km}^{2}$, then extracted each ecosystem service's information based on the hexagon. All processes were 
accomplished in ArcGIS10.3. The Pearson correlation was conducted with statistical units of hexagon, and the statistical analysis was implemented using SPSS 20.0.

\section{Identifying key areas}

A key area was defined as an area that provides large components of a particular service. In this study, we delineated key areas as the richest $10 \%$ of grid cells for each service class, including provisioning services, cultural services, and regulating services, following the practice in Xiao et al (2016). All ecosystem services were imported into the ArcGIS 9.3 (Environmental Systems Research Institute, ESRI) for analyses of trade-off and synergy. In order to eliminate the influence of different unit measurement per ecosystem service, we normalized each ecosystem service to a scale range (0-1) based on the formula $\left(\mathrm{x}-\mathrm{x}_{\min }\right) /\left(\mathrm{x}_{\max }-\mathrm{x}_{\min }\right)$, where the higher values corresponded to a greater supply of ecosystem services. We average normalization all ecosystem services in each service class, then sort and take the richest $10^{\text {th }}$ percentile (by area) of each service class as key areas. Finally, the key areas of trade-offs and synergies between each pair class (e.g. provisioning services and cultural services, provisioning services and regulating services, cultural services and regulating services) were identified by overlapping key area between each pair service (overlapped area).

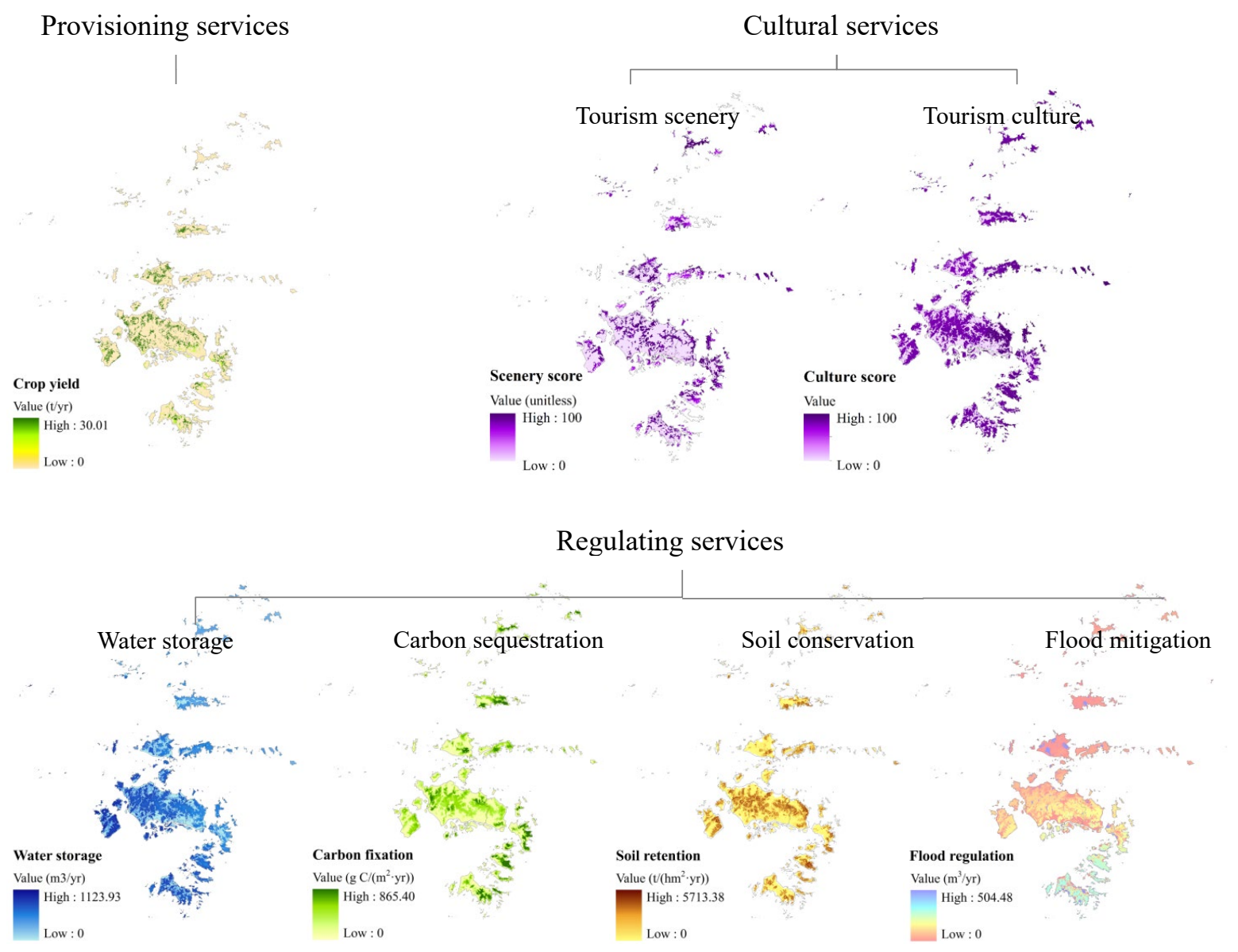

Figure 2: Spatial patterns of ecosystem services in Zhoushan Archipelago. 


\section{Results}

Spatial pattern of ecosystem services in Zhoushan Archipelago

The spatial distributions of the studied ecosystem services were obviously different across the landscape (Figure 2). The distribution of provisioning services was comparatively even, with dominant crop production ranging from 10-20 t/pixel. The ecosystem in the central and southeastern mountainous and hilly areas with a wide distribution of forest generally provided more valuable services, such as water storage (values $>600 \mathrm{~m}^{3} /$ pixel), carbon sequestration (values $>300 \mathrm{~g} \mathrm{C} / \mathrm{m}^{2}$ ), soil retention (values $>300 \mathrm{t} / \mathrm{hm}^{2}$ ), and flood regulation (values $>100$ $\mathrm{m}^{3}$ /pixel), relative to those provided by northern hilly areas with a low elevation. However, unlike the regulating services, the areas with high cultural services were mainly distributed across the northeastern and southeastern regions, which are well-known for their natural beauty and pristine ocean environments.

To understand the regional variation in ecosystem services, we analyzed the ecosystem services in the four sub-regions (counties): Dinghai, Putuo, Daishan, and Shengsi. Characteristics of ecosystem services in each county are provided in Table 3 . Water storage capacities were highest in Dinghai, and Putuo was found to have the highest carbon sequestration and flood mitigation capacities. Shengsi has the highest soil conservation and best tourism capacities.

Table 3: Characteristics of ecosystem services in each county.

\begin{tabular}{|c|c|c|c|c|c|c|}
\hline County & $\begin{array}{l}\text { Crop } \\
\text { production }\end{array}$ & $\begin{array}{l}\text { Water } \\
\text { storage }\end{array}$ & Tourism & $\begin{array}{l}\text { Carbon } \\
\text { sequestration }\end{array}$ & $\begin{array}{l}\text { Soil } \\
\text { conservation }\end{array}$ & $\begin{array}{l}\text { Flood } \\
\text { mitigation }\end{array}$ \\
\hline & $\left(\mathrm{t} / \mathrm{hm}^{2}\right)$ & $\left(\mathrm{m}^{3} / \mathrm{hm}^{2}\right)$ & (unitless) & $\left(\mathrm{t} \mathrm{C} / \mathrm{hm}^{2}\right)$ & $\left(\mathrm{t} / \mathrm{hm}^{2}\right)$ & $\left(\mathrm{m}^{3} / \mathrm{hm}^{2}\right)$ \\
\hline Dinghai & 120.82 & 5749.30 & 31.58 & 1.76 & 522.34 & 892.75 \\
\hline Putuo & 95.08 & 5105.08 & 47.47 & 2.01 & 543.69 & 1760.84 \\
\hline Daishan & 143.12 & 4617.50 & 43.78 & 1.74 & 399.60 & 901.27 \\
\hline Shengsi & 295.40 & 3755.36 & 55.59 & 1.71 & 606.27 & 938.98 \\
\hline
\end{tabular}

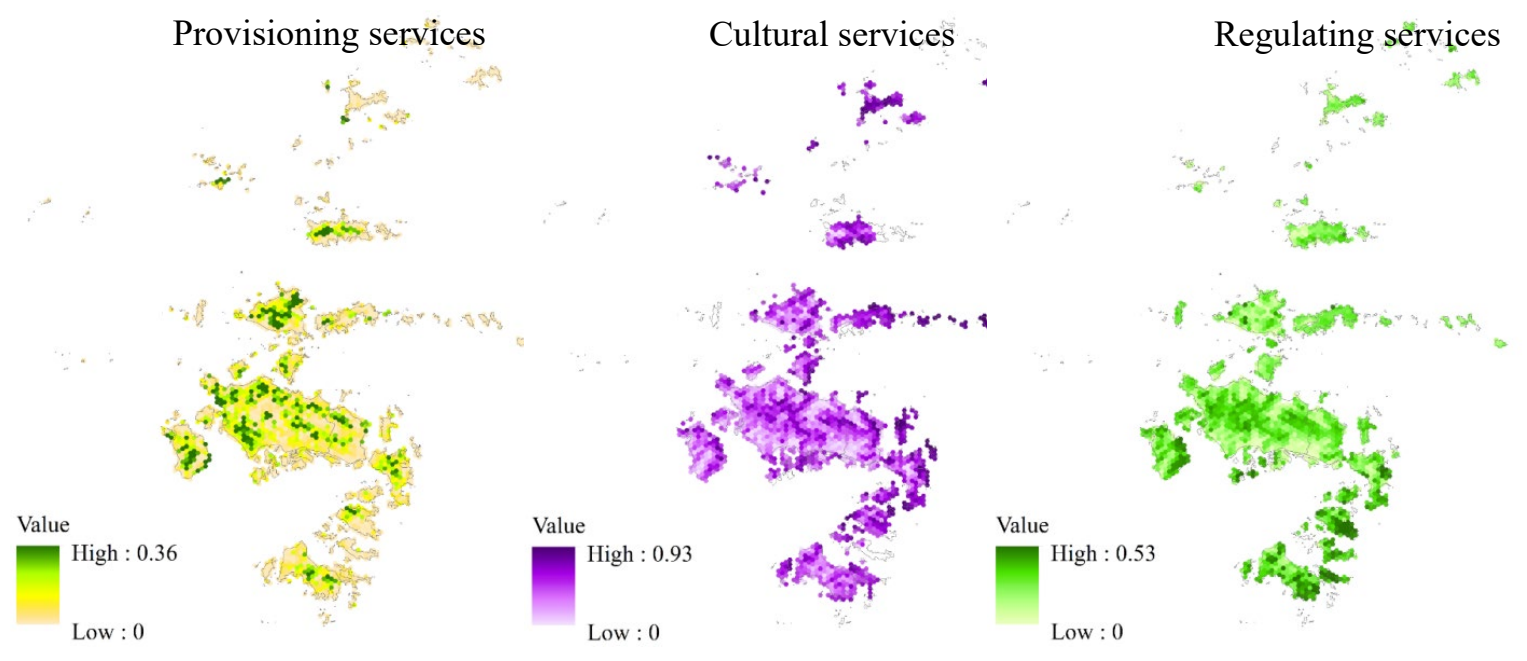

Figure 3: Spatial characteristics of normalized ecosystem services in Zhoushan Archipelago (hexagon as statistical unit). 
Trade-offs and synergies among ecosystem services

The normalization maps of ecosystem services below show the spatially comprehensive characteristics of the three types of ecosystem services (provisioning services, cultural services, and regulating services) (Figure 3). We can see that Dinghai and Daishan have the highest value of production services, Shengsi has the richest value of cultural services, and Putuo has the highest capacity of regulating services.

Pearson correlations between ecosystems services were very high (Table 4): Pearson's $r$ results indicated very significant correlations. Almost all ecosystem services are positively correlated, except for crop production. Crop production showed a negative correlation with other ecosystem services, with the highest negative correlation with soil conservation $(-0.403)$. Generally, the highest correlation was between carbon sequestration and soil conservation (0.619), which was also a positive correlation. In general, provisioning services showed a negative correlation with cultural services and regulating services, indicating a trade-off between them. Cultural services showed a positive correlation with regulating services, pointing to a synergy between them.

Table 4: Pearson correlation analysis among ecosystem services, on the basis of $1 \mathrm{~km}^{2}$ hexagon within Zhoushan. Note: while ' $\star$ ' means significant level $(\mathrm{p}<0.05)$, ‘ $\star \star$ ' means very significant level $(\mathrm{p}<0.01)$, and the number in parentheses means the sample number.

\begin{tabular}{llllll}
\hline & \multicolumn{3}{c}{ Provisioning services } & Cultural services & \multicolumn{2}{c}{ Regulating services } \\
& $\begin{array}{l}\text { Crop } \\
\text { production }\end{array}$ & Tourism & $\begin{array}{l}\text { Carbon } \\
\text { storage }\end{array}$ & $\begin{array}{l}\text { Soil } \\
\text { sequestration }\end{array}$ & $\begin{array}{l}\text { Flood } \\
\text { conservation }\end{array}$ \\
mitigation
\end{tabular}

In order to identify key areas in which future land policy implementation may be necessary, we restricted our analysis to relationships between provisioning services, cultural services, and regulating services, obtained by overlapping the four regulating ecosystem services into one with the same weight. The red areas representing ecosystem service trade-offs (provisioning services vs cultural services and provisioning services vs regulating services) indicate a need for caution when the government selects service providers to develop 1) either agriculture or tourism and 2) agriculture or regulation services. Moreover, the green areas representing ecosystem service synergy might constitute priorities for future policies, mostly situated in rural eastern Zhoushan (Figure 4). 

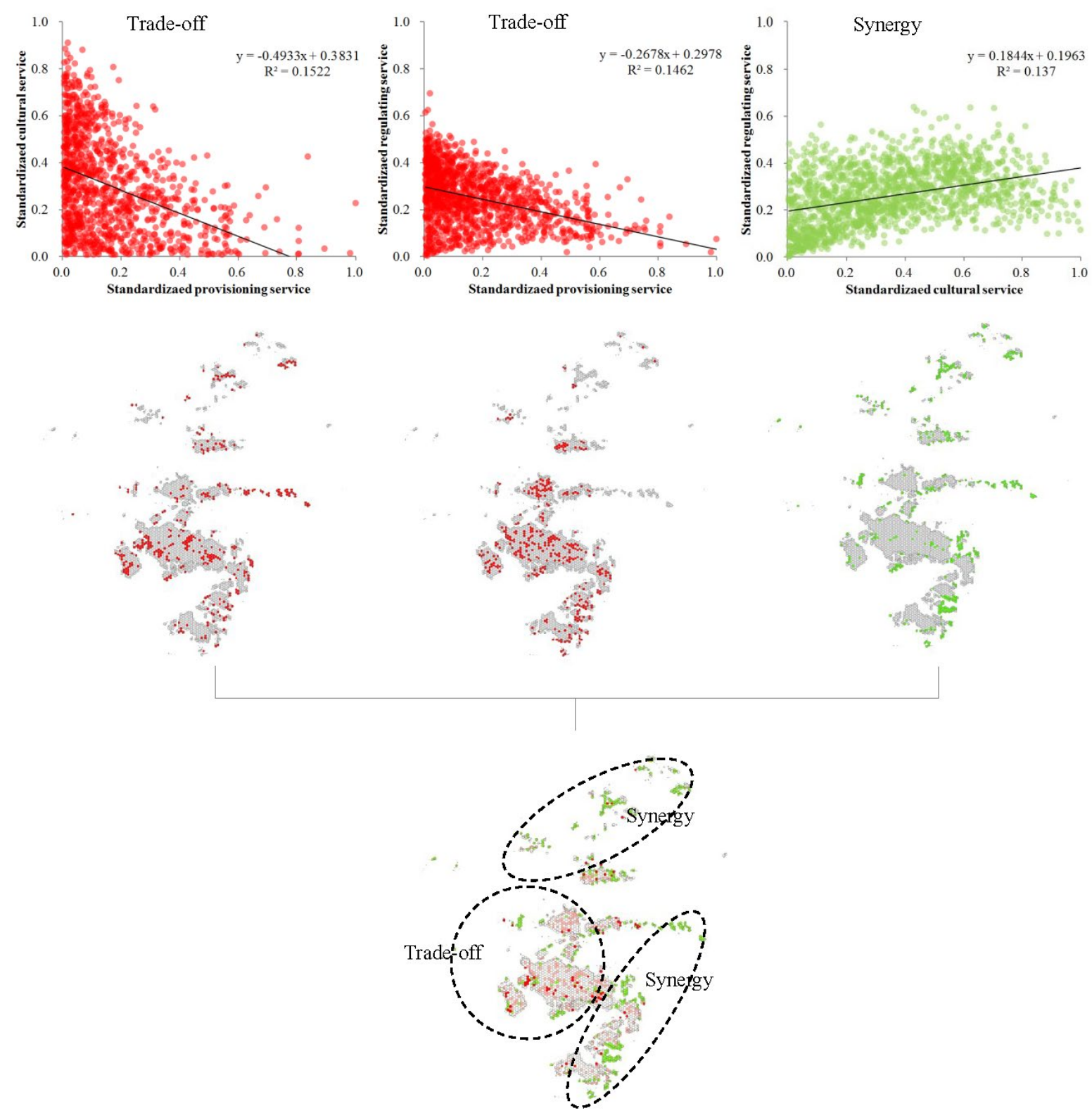

Figure 4: Key areas identified as priorities for future land policy implementation in Zhoushan Archipelago. A trade-off relationship exists in provisioning services relative to cultural services and provisioning services relative to regulating services (red color). A synergetic relationship was found in cultural services relative to regulating services (green color).

\section{Discussion}

Our research finds that the six ecosystem services possess very different spatial distributions within the archipelago. The distribution of supply services is relatively uniform. One of the key types of research in the field of ecosystem services focuses on identifying the providers of ecosystem services and their functional relationships. It is believed that a 'function list' can be constructed to clarify the importance of ecosystem service providers as well as to measure and estimate the contribution of each ecosystem service provider to the population function (Wang et $\mathrm{al}, 2014)$. The distribution of supply services in this study is fairly uniform, possibly because, 
among longstanding island communities, the land suitable for the supply services is used to grow food, without adequately considering other local service functions.

The wider ecosystem services in Zhoushan Archipelago also show that the areas with highest cultural services are mainly distributed across the northeast and southeast regions, both in areas known for their stunning natural features and pristine ocean environments (Yue et al, 2017). Generally speaking, ecosystem service functions form the basis for human survival and development. Strengthening the management, conservation, and restoration of ecosystem service functions is an important means of ensuring regional sustainable development (Qiu et al, 2017). A comprehensive understanding of the ecological mechanisms behind ecosystem services is a precondition for ecosystem service function management. Human understanding of ecosystem services is, however, a gradual process.

The northeast and southeast regions of Zhoushan Archipelago have previously been subject to a degree of planning neglect, with little effort being made to integrate them into the archipelago's new economic focus on shipping, port services, and marine technology. This has contributed to localized depopulation (Yue et al, 2017), but our study indicates that it may also have contributed to a localised concentration of cultural services, which themselves hold economic value for the archipelago. Localized planning neglect within an archipelago can thus sometimes lead to beneficial results on the island scale if the plan itself is problematic.

During the study, we find that crop yield is negatively correlated with other ecosystem services and with soil conservation, which was similar to the findings of other researchers (Qiu et al, 2013). From a natural resource management perspective, we regard management of demand as a key goal (Xiao et al 2016). In light of the importance of this ecosystem service function, we identify the ecological mechanism of the ecosystem service and advance the key indicators that affect the ecosystem service supply (Gotelli et al, 2011). For example, it has become clear that, despite the prevalence of small-scale agriculture within the archipelago, the archipelago does not possess an especially suitable environment for cultivating crops; it is instead ideal for tourism development. There are serious multiple correlations between crop production and soil conservation. Our results suggest that it is both more economically worthwhile and environmentally sustainable to import food from elsewhere and thereby protect local soil from erosion than it is to grow food locally.

In the study, we found that cultural services showed a positive correlation with regulating services, pointing to a synergy between them. This suggests that the differences in trade-offs between ecosystem services may be caused by allocation of land use strategies (such as land used for agriculture or for ecological protection) as well as spatial and temporal distribution characteristics of natural resources as a result of the interactions between climate, vegetation topography, human activities, etc. (Cao et al, 2017; Liu et al, 2019). Therefore, when undertaking spatial management of landscape types in Zhoushan Archipelago, it is necessary to improve the ecosystem regulating service and at the same time coordinate and maintain the relationship between other ecosystem service functions. Generally speaking, for the purpose of regional ecosystem services, it is necessary to first map the regional ecosystem services, then select the appropriate evaluation method according to the decision-making needs, and finally to identify the spatial characteristics of key areas in terms of synergies and trade-offs between ecosystem services (Fu et al, 2018). 
In addition, we have explored methods of identifying key areas, bearing in mind synergies and trade-offs between ecosystem services, in order to clarify the mechanisms of island ecosystem services. This could assist in coordinating relationships among various stakeholders (national government, provincial government, city government, businesses of various sizes, and residents on various islands) in Zhoushan Archipelago and promote coordinated development in the region. It may be prudent for decision-makers to choose between development of 1) agriculture or tourism and 2) agriculture or regulatory services.

\section{Conclusions}

Our study calls into question the wisdom of the city government's homogenizing 'One Appearance of a Thousand Islands' 千岛一面 strategy, which smooths over intra-archipelagic difference and thus misses out on ecosystem service synergies and trade-offs among the islands.

In our results, the synergy areas are mainly distributed in the overlapping area between cultural and regulating services. These could potentially be prioritized by future policies, especially given that they are situated in the rural eastern part of Zhoushan Archipelago. The spatial distribution of regulating services in the study area is consistent with soil conservation and water conservation. More generally, these results seem to be due to the concentration of cultural services in northeastern and southeastern region, which are characterized by beautiful natural scenery and pristine ocean environments.

Ultimately, by shedding light on the trade-off relationships between provisioning services vs cultural services as well as between provisioning services vs regulating services, the present study has emphasized the need for careful local contextualization of sustainable development planning. Although integrated and holistic planning is vital, such planning should avoid assuming environmental and economic homogeneity even within a limited spatial area. This may be particularly true among islands within an archipelago, which may possess shared economic, social, and environmental interests but also possess differing needs, strengths, and vulnerabilities.

An improved understanding of localized provision of ecosystem services could effectively promote economic development in Zhoushan Archipelago, thereby facilitating the coexistence of economic development and environmental protection.

\section{References}

Bateman, I. J., Harwood, A. R., Mace, G. M., Watson, R. T., Abson, D. J., Andrews, B., Binner, A., Crowe, A., Day, B. H., Dugdale, S., Fezzi, C., Foden, J., Hadley, D., HainesYoung, R., Hulme, M., Kontoleon, A., Lovett, A. A., Munday, P., Pascual, U., Paterson, J., Perino, G., Sen, A., Siriwardena, G., van Soest, D., \& Termansen, M., (2013). Bringing ecosystem services into economic decision-making: Land use in the United Kingdom. Science, 341, 45-50. https://doi.org/10.1126/science.342.6157.421-b

Bertolo, L. S., Lima, G. T. N. P., \& Santos, R. F., (2012). Identifying change trajectories and evolutive phases on coastal landscapes: Case study São Sebastião Island, Brazil. Landscape and Urban Planning, 106, 115-123. https://doi.org/10.1016/j.landurbplan.2012.02.009

Bureau of Zhoushan Statistics (2016). Zhoushan Statistical Yearbook. Beijing: China Statistics Press. 
Chen, N., Li, H., \& Wang, L. (2009). A GIS-based approach for mapping direct use value of ecosystem services at a county scale: Management implications. Ecological Economics, 68(11), 2768-2776. https://doi.org/10.1016/j.ecolecon.2008.12.001

Chen, S. T., Huang, Y., Zou, J. W., Shi, Y. S., Lu, Y. Y., Zhang, W., \& Hu, Z. H. (2012). Interannual variability in soil respiration from terrestrial ecosystems in China and its response to climate change. Science China Earth Sciences, 55(12), 2091-2098. https://doi.org/10.1007/s11430-012-4464-6

Chen, J., Pan, D., Mao, Z., Chen, N., Zhao, J., \& Liu, M. (2013). Land-cover reconstruction and change analysis using multisource remotely sensed imageries in Zhoushan Islands since 1970. Journal of Coastal Research, 30, 272-282. https://doi.org/10.2112/jcoastres-d-13$\underline{00027.1}$

Christie, M., \& Rayment, M. (2012). An economic assessment of the ecosystem service benefits derived from the SSSI biodiversity conservation policy in England and Wales. Ecosystem Services, 1(1), 70-84. https://doi.org/10.1016/j.ecoser.2012.07.004

Cao, S., Shang, D., Yue, H., \& Ma, H. (2017). A win-win strategy for ecological restoration and biodiversity conservation in Southern China. Environmental Research Letters, 12(4), 044004. https://doi.org/10.1088/1748-9326/aa650c

Costanza, R., de Groot, R., Sutton, P., van der Ploeg, S., Anderson, S.J., Kubiszewski, I., Farber, S., \& Turner, R.K. (2014. Changes in the global value of ecosystem services. Global Environmental Change, 26, 152-158. https://doi.org/10.1016/j.gloenvcha.2014.04.002

Daily, G. C., Söderqvist, T., Aniyar, S., Arrow, K., Dasgupta, P., Ehrlich, P. R., Folke, C., Jansson, A., Jansson, B. O., \& Kautsky, N. (2000). The value of nature and the nature of value. Science, 289(5478), 395-396. https://doi.org/10.1007/978-90-481-9476-6 19

Fu, B., Liu, Y., Lü, Y., He, C., Zeng, Y., \& Wu, B. (2011). Assessing the soil erosion control service of ecosystems change in the Loess Plateau of China. Ecological Complexity, 8(4), 284-293. https://doi.org/10.1016/j.ecocom.2011.07.003

Fu, B., \& Wei, Y. (2018). Editorial overview: Keeping fit in the dynamics of coupled natural and human systems. Current Opinion in Environmental Sustainability, 33, A1-A4. https://doi.org/10.1016/j.cosust.2018.07.003

Gotelli, N. J., Ulrich, F. W., \& Maestre F. T. (2011). Randomization tests for quantifying species importance to ecosystem function. Methods in Ecology and Evolution, 2(6), 634-642. https://doi.org/10.1111/j.2041-210x.2011.00121.x

Grydehøj, A. (2019). Marine island economies: Drivers, roles, and challenges. In The 21st Century Maritime Silk Road: Islands Economic Cooperation Forum - Annual report on global islands. Charlottetown: Island Studies Press.

Hickey, R. (2000). Slope angle and slope length solutions for GIS. Cartography, 29(1), 1-8. https://doi.org/10.1080/00690805.2000.9714334

Ivits, E., Cherlet, M., Sommer, S., \& Mehl, W. (2013) Addressing the complexity in non-linear evolution of vegetation phenological change with time-series of remote sensing images. Ecological Indicators, 26(3), 49-60. https://doi.org/10.1016/j.ecolind.2012.10.012

Johnson, F., Hutchinson, M. F., The, C., Beesley, C., \& Green, J. (2016). Topographic relationships for design rainfalls over Australia. Journal of Hydrology, 533, 439-451. https://doi.org/10.1016/j.jhydrol.2015.12.035 
Lin, T., Xue, X., Shi, L., \& Gao, L. (2013). Urban spatial expansion and its impacts on island ecosystem services and landscape pattern: A case study of the island city of Xiamen, Southeast China. Ocean \& Coastal Management, 81, 90-96. https://doi.org/10.1016/j.ocecoaman.2012.06.014

Liu, Y., Li, T., Zhao, W., Wang, S., \& Fu, B. (2019). Landscape functional zoning at a county level based on ecosystem services bundle: Methods comparison and management indication. Journal of Environmental Management, 249, 109315. https://doi.org/10.1016/j.jenvman.2019.109315

Long, H., Liu, Y., Hou, X., Li, T., \& Li, Y. (2014). Effects of land use transitions due to rapid urbanization on ecosystem services: Implications for urban planning in the new developing area of China. Habitat International, 44, 536-544. https://doi.org/10.1016/j.habitatint.2014.10.011

Lufafa, A., Tenywa, M. M., Isabirye, M., Majaliwa, M. J. G., \& Woomer, P. L. (2003). Prediction of soil erosion in a Lake Victoria basin catchment using a GIS-based Universal Soil Loss model. Agricultural Systems, 76(3), 883-894. https://doi.org/10.1016/s0308$\underline{521 x}(02) 00012-4$

Ouyang, Z. Y., Zheng, H., Xiao, Y., Polasky. S., Liu, J., Xu, W., Wang, Q., Zhang, L., Xiao, W., Rao, E., Jiang, L., Lu, F., Wang, X., Yang, G., Gong, S., Wu, B., Zeng, Y., Yang, W., \& Daily, G.C. (2016). Improvements in ecosystem services from investments in natural capital. Science, 352(6292), 1455-14 59. https://doi.org/10.1126/science.aaf2295

Piao, S. L., Fang, J. Y., \& Guo, Q. H. (2001). Application of CASA model to the estimation of Chinese terrestrial net primary productivity. Acta Phytoecologica Sinica, 25, 603-608.

Potter, C. S., Randerson, J. T., Field, C. B., Matson, P. A., Vitousek, P. M., Mooney, H. A., \& Klooster, S. (1993). Terrestrial ecosystem production: A process model based on global satellite and surface data. Global Biogeochemical Cycles. 7(4), 811-841. https://doi.org/10.1029/93gb02725

Qiu, J., \& Turner, M. G. (2013). Spatial interactions among ecosystem services in an urbanizing agricultural watershed. Proceedings of the National Academy of Sciences, 110(29), 12149-12154. https://doi.org/10.1073/pnas.1310539110

Qiu, S., Yue, W., Zhang, H., \& Qi, J. (2017). Island ecosystem services value, land-use change, and the National New Area Policy in Zhoushan Archipelago, China. Island Studies Journal, 12(2), 177-198. https://doi.org/10.24043/isj.20

Wang, X., Chen, W., Zhang, L., Jin, D., \& Lu, C. (2010). Estimating the ecosystem service losses from proposed land reclamation projects: A case study in Xiamen. Ecological Economics, 69(12), 2549-2556. https://doi.org/10.1016/j.ecolecon.2010.07.031

Wang, D., Shi, A., Wang, X., Zhang, Z., \& Sounghook, H. (2014). Assessment of island land ecosystem services value and their spatial distribution. Nature Environment and Pollution Technology, 13(4), 743.

Wischmeier, W. H., \& Smith, D. D. (1978). Predicting rainfall erosion losses: A guide to conservation planning. Washington, D.C.: Agriculture Handbooks.

Xiao, Y., Ouyang, Z. Y., Xu, W. H., Xiao, Y., Zheng, H., \& Xian, C. F. (2016). Optimizing hotspot areas for ecological planning and management based on biodiversity and ecosystem services. Chinese Geographical Science, 26(2), 256-269. https://doi.org/10.1007/s11769-016-0803-4 
Xiao, Y., \& Xiao, Q. (2018). Identifying key areas of ecosystem services potential to improve ecological management in Chongqing City, southwest China. Environmental Monitoring \& Assessment, 190(4), 258. https://doi.org/10.1007/s11769-018-0984-0

Xiao, Y., \& Ouyang, Z. (2019). Spatial-temporal patterns and driving forces of water retention service in China. Chinese Geographical Science, 29(1), 100-111.

Yue, W., Qiu, S., Zhang, H., \& Qi, J. (2017). Migratory patterns and population redistribution in China's Zhoushan Archipelago in the context of rapid urbanization. Island Studies Journal, 12(2), 45-60. https://doi.org/10.24043/isj.23

Zhang, K. L., Shu, A. P., Xu, X. L., Yang, Q. K., \& Yu, B. (2008). Soil erodibility and its estimation for agricultural soils in China. Journal of Arid Environments, 72(6), 1002-1011. https://doi.org/10.1016/j.jaridenv.2007.11.018 